\section{Bush slips off the hook over funds for ocean management}

Rex Dalton, San Diego

A top-level panel's demand for major reforms in US ocean management and research is getting the brush-off from the White House, say some of its members.

In a low-key announcement on 17 December, President George W. Bush said that he would set up an advisory committee to study the 212 recommendations of the Commission on Ocean Policy. These were published in September after a huge review of issues that ranged from fisheries conservation to coastal pollution.

But commission members are frustrated because Bush failed to promise substantial new funding. The commission's recommendations would have cost about $\$ 1.5$ billion in the first year, ramping up to nearly $\$ 4$ billion in annual spending after five years, according to its chairman, James Watkins, a former energy secretary.

"I'm a bit disappointed," says Andrew Rosenberg, a commission member and a fisheries scientist at the University of New Hampshire, Durham. The administration's response, which it was legally required to issue, "is very much a fig leaf", he says.

And Watkins himself says that the White House "fails to hit the nail on the head". Current funding for managing coastal waters "is inadequate", Watkins says, and the response does not specify by how much it should be increased. The oceans are "a precious resource", he adds, "and we don't have much time."

The commission was established by Congress in the final year of the Clinton administration in a bid to reinvigorate US ocean policy, but its members were chosen by the Bush administration. It took three years to research its findings, which are similar to, but milder than, those of a privately funded panel, the Pew Oceans Commission.

Environmental groups are even more critical of Bush's plan. "It's a big yawn; there is nothing there but a lot of hot air," says Gerry Leape, marine programme director at the National Environmental Trust. "It is a real missed opportunity."

But James Connaughton, a lawyer and chairman of the White House's Council on Environmental Quality, says that the administration will pursue a concrete response to the commission's recommendations. A list of research programmes worth supporting will be compiled by March 2005, he pledges.

\section{US proves a wet blanket at international climate meeting}

\section{Amanda Haag, Buenos Aires}

The latest global meeting on climate change wrapped up in Argentina this week, having made only modest steps towards cutting future greenhouse-gas emissions.

Delegates from many nations said that the United States and its allies, such as Saudi Arabia, thwarted progress at the tenth meeting of the Conference of Parties to the UN Framework Convention on Climate Change.

From 6 to 17 December, representatives of some 200 countries got together to discuss present and future climate-change negotiations. Russia's recent ratification of the Kyoto agreement on reducing greenhouse-gas emissions brings the protocol into force, so many delegates were keen to talk about what might happen after 2012, when Kyoto obligations expire. But the United States opposed such discussions. "We need to absorb and new actions," says Paula Dobriansky, head of the US delegation to the meeting.

During the conference, the United States strongly opposed the idea of using any seminars scheduled between now and next November to jump-start discussions about 2012 and beyond. Environmental groups attacked this position as deliberately obstructive. "I really think they've sunk to a new low here, by not only taking their own path but actively blocking other countries from pursuing the path they want to take," says Jeff Fiedler, climate policy specialist with the New York-based Natural Resources Defense Council.

"They never answered the question 'why are you objecting, why don't you just step aside' even though we asked them multiple times," says Debbie Reed, legislative director with the National Environmental Trust, a Washington-based environmental coalition. analyse lessons learned before committing to
Delegates haggled until sunrise on the last day of the conference over the wording that will regulate the seminars. In the end, it was agreed that just one seminar would take place before the next annual meeting to "promote an informal exchange of information" and to "continue to develop" appropriate responses to climate change. This at least leaves an opening for discussions about policy after 2012, says Elliot Diringer, director of international strategies with the Virginia-based Pew Center on Global Climate Change.

In future, the United States may have less sway over such issues. The 2005 conference will be split into two sections, one stream of which will be for Kyoto parties only: US delegates may not be able to take part in these sessions.

Saudi Arabia also caused dissent at the meeting, by asking for money from the 'adaptation fund' to offset the economic losses it will suffer when petroleum exports are reduced. By 2010, the country expects lost fossil-fuel exports to cost it billions of dollars annually. But the adaptation fund is meant predominantly to compensate developing countries and vulnerable island nations.

Although Saudi Arabia always raises the issue of compensation, this year's suggestion that it be provided by the adaptation fund was especially contentious, says Reed."We're having a hard time raising money for developing countries," says Reed. "So for a country like Saudi Arabia to demand compensation for lost sales of oil - it's worse than ironic."

Despite these difficulties, the meeting struck some hopeful notes. The European Union and other nations renewed a pledge to deposit \$420 million annually, beginning in 2005, to fund developing countries' efforts. And, following Russia's lead, Indonesia and Nigeria have ratified the Kyoto Protocol.

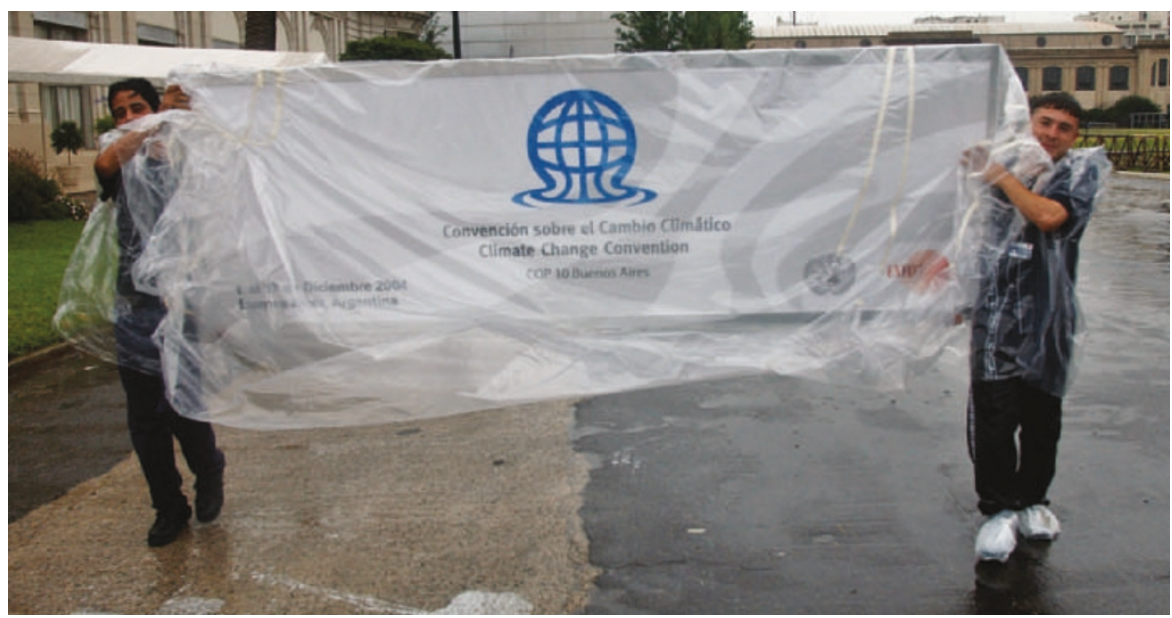

Raining on the parade: the United States put a dampener on the tenth UN climate-change convention. 